Supplement of Biogeosciences, 18, 2289-2300, 2021 https://doi.org/10.5194/bg-18-2289-2021-supplement (C) Author(s) 2021. CC BY 4.0 License.

(c) (1)

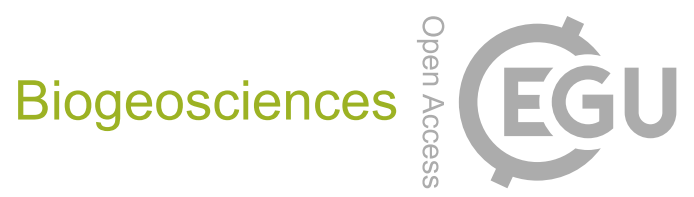

Supplement of

\title{
Lignin oxidation products in soil, dripwater and speleothems from four different sites in New Zealand
}

Inken Heidke et al.

Correspondence to: Thorsten Hoffmann (t.hoffmann@uni-mainz.de)

The copyright of individual parts of the supplement might differ from the article licence. 


\section{S1 Analytical methods}

For the soil samples, the LC-MS analysis of the lignin oxidation products was performed as described in Heidke et al. (2018) using a $50 \mathrm{~mm}$ pentafluorophenyl (PFP) column (Hypersil GOLD PFP, $50 \mathrm{~mm} \times 2.1 \mathrm{~mm}$ with $1.9 \mu \mathrm{m}$ particle size by Thermo Fisher Scientific). For the dripwater and flowstone samples, a $100 \mathrm{~mm}$ PFP column (Aquity UPLC CSH Fluoro-Phenyl, $100 \mathrm{~mm}$ $5 \times 2.1 \mathrm{~mm}$ with $1.7 \mu \mathrm{m}$ particle size by Waters) was used for the separation of the LOPs. The gradient for this column started with $5 \%$ eluent $B\left(98 \%\right.$ acetonitrile, $\left.2 \% \mathrm{H}_{2} \mathrm{O}\right)$ and $95 \%$ eluent $\mathrm{A}\left(98 \% \mathrm{H}_{2} \mathrm{O}, 2 \%\right.$ acetonitrile and $0.4 \mu \mathrm{L} \cdot \mathrm{L}^{-1}$ formic acid). Eluent B increased to $10 \%$ until $0.5 \mathrm{~min}$, was held at this stage until $5.0 \mathrm{~min}$, increased to $15 \%$ until $6.0 \mathrm{~min}$ and to $50 \%$ until $7.5 \mathrm{~min}$. Then, a cleaning step at $99 \% \mathrm{~B}$ was run from 7.5 to $9.5 \mathrm{~min}$, and finally, the initial eluent mixture with $5 \%$ B was reequilibrated from 9.5 to $11.0 \mathrm{~min}$. The flow was set to $500 \mu \mathrm{L} \cdot \mathrm{min}^{-1}$ and the column oven was heated to $40{ }^{\circ} \mathrm{C}$.

The electrospray ionisation source (ESI) was operated in negative mode, so that deprotonated molecular ions $[\mathrm{M}-\mathrm{H}]^{-}$were formed. The spray voltage was $-3.5 \mathrm{kV}$, the ESI probe was heated to $150{ }^{\circ} \mathrm{C}$ to improve the evaporation of the aqueous solvent, the capillary temperature was $320^{\circ} \mathrm{C}$, the sheath gas pressure was $60 \mathrm{psi}$ and the auxiliary gas pressure was $20 \mathrm{psi}$.

The mass spectrometer(Q Exactive Orbitrap high-resolution mass spectrometer by Thermo Fisher Scientific) was operated in full scan mode with a resolution of 70000 and a scan range of $m / 2$ 80-500. At the respective retention time windows, the full scan mode was alternated with a targeted $\mathrm{MS}^{2}$-mode with a resolution of 17500 to identify the LOPs by their specific daughter ions (Heidke et al., 2018). For the $\mathrm{MS}^{2}$-mode (i.e., parallel reaction monitoring mode in the software XCalibur, provided by Thermo Fisher Scientific), higher-energy collisional dissociation (HCD) was used with 35\% normalized collision energy (NCE) for all analytes. 


\section{S2 Description of the cave sites}

Soils have been described to the most appropriate soil order following the New Zealand Soil Classification (NZSC, Hewitt (2010)). A brief description of the vegetation and soils of the four different cave sites is given in the following paragraphs.

Waipuna Cave, Waitomo (Fig. S1, situated at S $38.3114722^{\circ}$, E $175.0206389^{\circ}$ ), is covered by a lush podocarp forest with 5 a dense undergrowth of shrubs, ferns and tree-ferns. Soils in the locality are deep (>1m) typic orthic allophanic (LO) being developed on extensive North Island rhyolitic volcanic ash deposits. These soils are exceptionally well drained and water typically reaches the cave on the timescale of days to a few weeks following rainfall events (Nava-Fernandez et al., 2020).

(a)

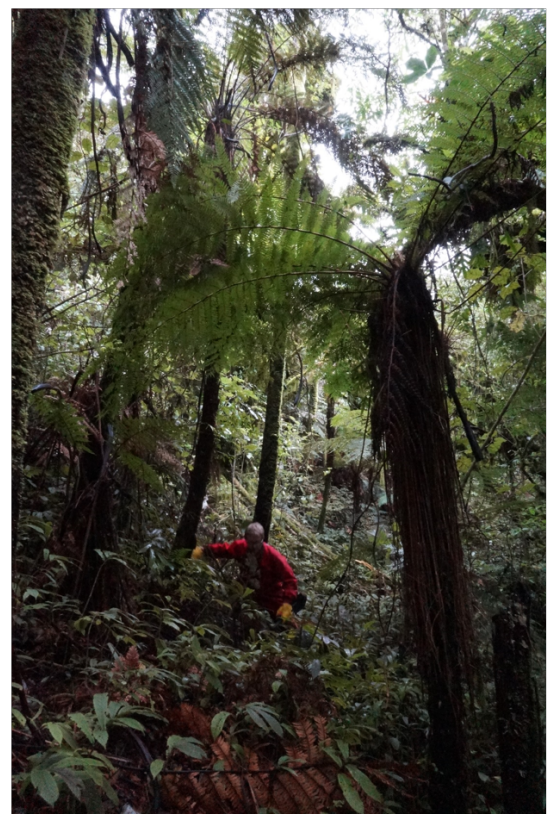

(b)

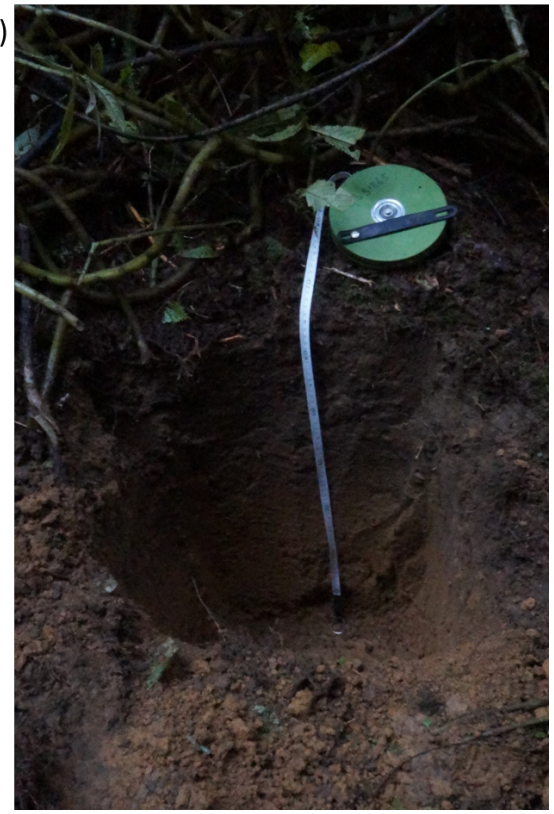

Figure S1. Vegetation (a) and soils (b) of Waipuna Cave, Waitomo, North Island.

Hodges Creek Cave, Mt Arthur Tablelands, (Fig. S2, situated at S $41.171270^{\circ}$, E $172.685941^{\circ}$ ) is developed within an Oligocene limestone remnant that has been heavily weathered and incised by deep grykes within which extensive litter organic (LO) soils have accumulated, which in places transition to orthic gley (GO) due to water logging leading to iron reduction, with characteristic iron mottles and concretions being found at depth (right hand picture). On the more gentle slopes, mature beech forest and well-drained orthic podzol (ZO) soils are typical with a deep brown O horizon and a weak sub-soil composed of bleached clays and weathered limestone.

The steep beech-covered slopes of Mt Arthur have only a thin orthic podzol (ZO) soil (Fig. S3, Nettlebed Cave situated at $15 \mathrm{~S} 41.2104589^{\circ}, \mathrm{E} 172.7394572^{\circ}$ ). Typically they are well-drained with a weak, bleached sub-soil due to the abundant, acidic leaf litter. 

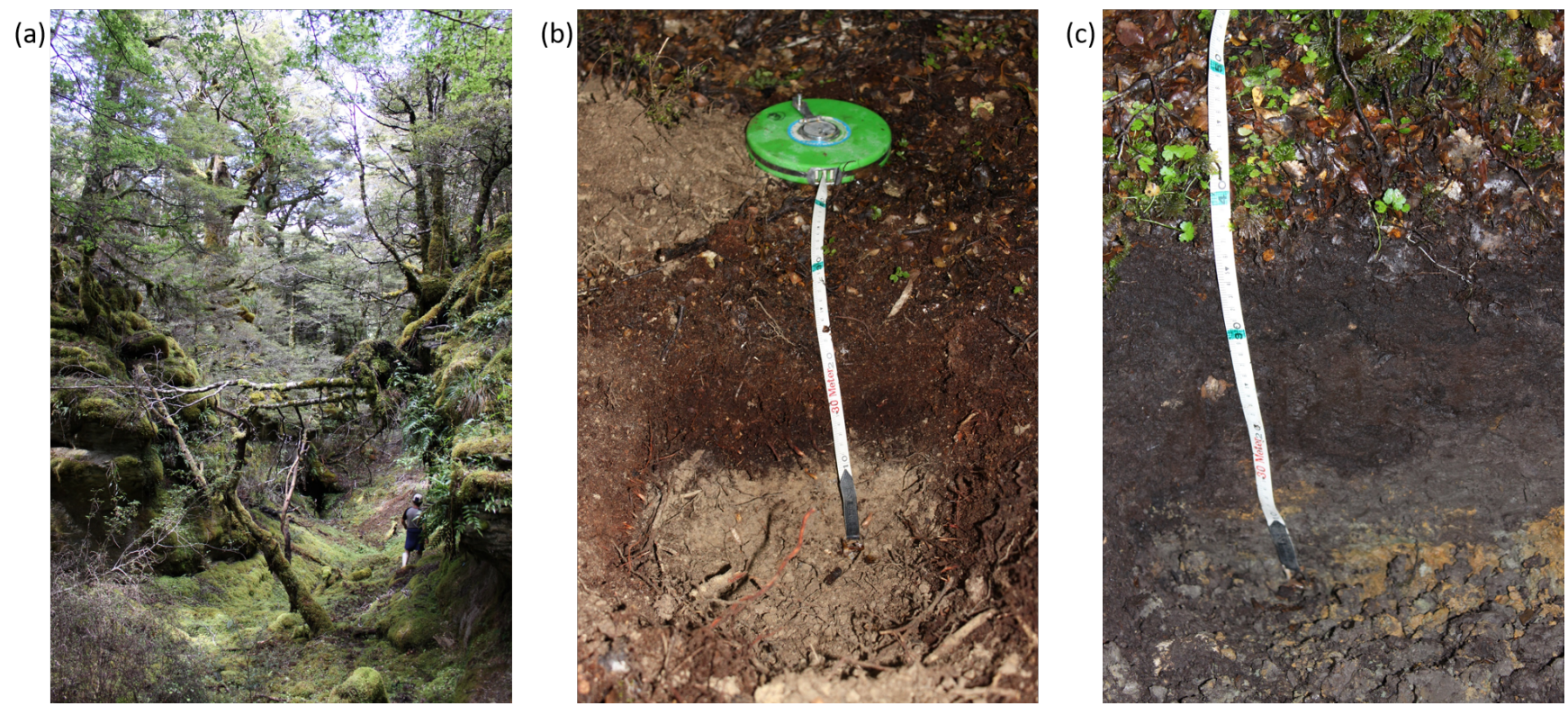

Figure S2. Vegetation (a) and soils (b) and (c) of Hodges Creek Cave, Mt Arthur Tablelands, Kahurangi National Park, South Island.

(a)

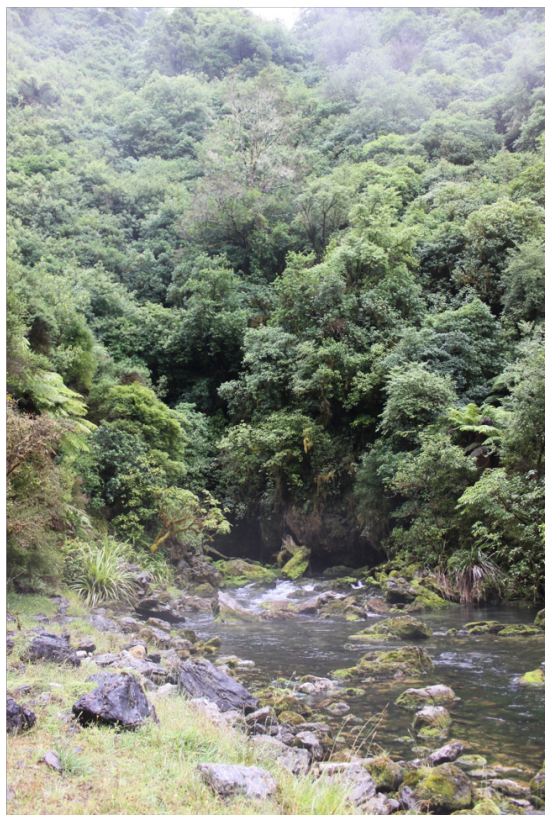

(b)

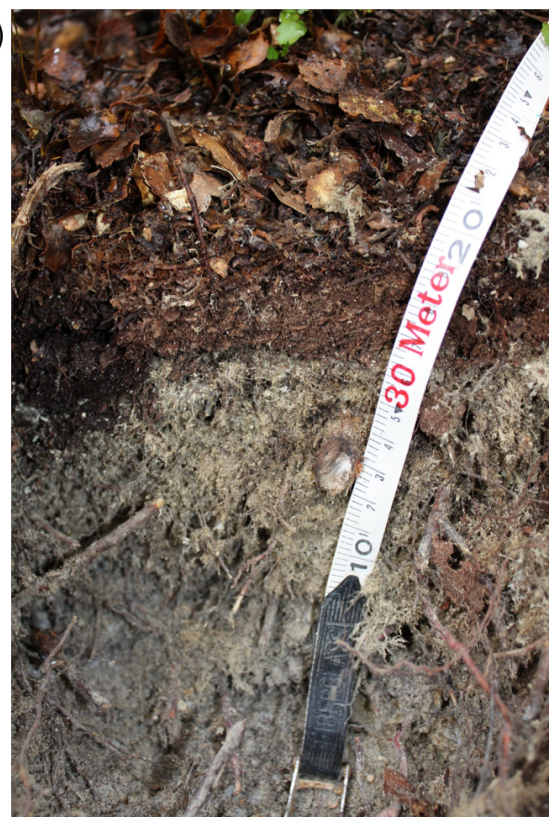

Figure S3. Vegetation (a) and soils (b) of Nettlebed Cave, Mt Arthur, Kahurangi National Park, South Island. 
The Mt Luxmore caves (Fig. S4, Daves cave situated at S $45.3894900^{\circ}, \mathrm{E} 167.6153448^{\circ}$ ) reside above the tree line under a thick ground cover of tussock and other native alpine plants. Cold and wet conditions promote water-logging and peaty organic rich soils have developed. Soils were found to have light brown A horizons beginning at around $20 \mathrm{~cm}$ with characteristic iron staining indicating iron reduction and oxidation within the soil profile.

(a)

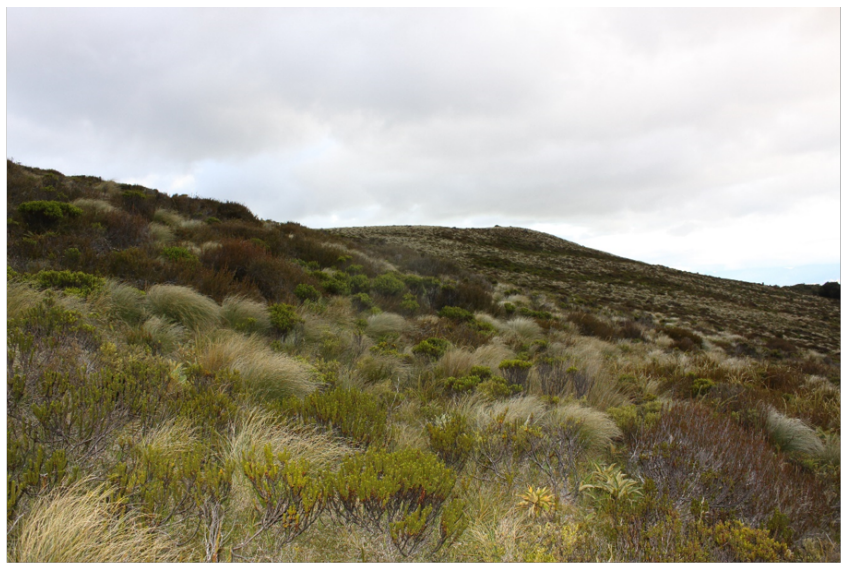

(b)

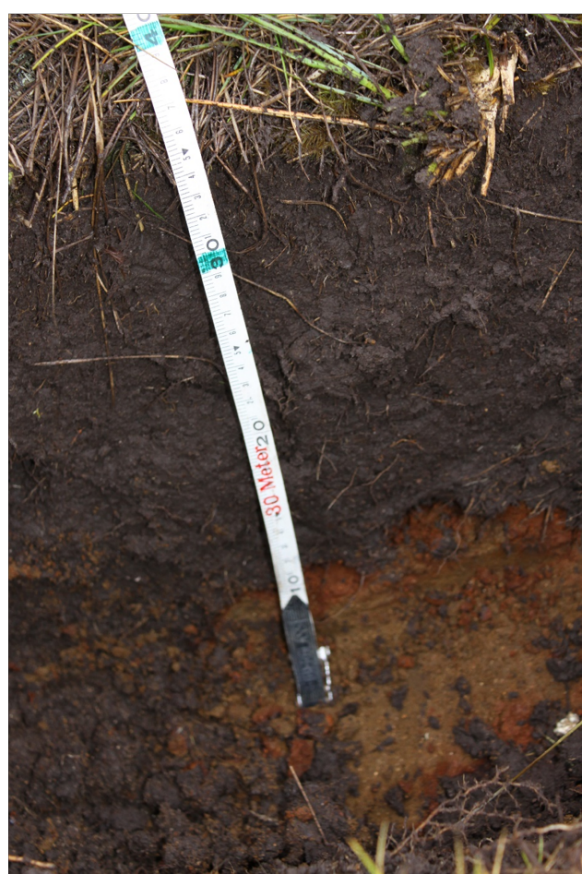

Figure S4. Vegetation (a) and soils (b) of Dave's Cave, Mt Luxmore, Fiordland National Park, South Island. 


\section{S3 Photographs of the flowstone samples}

In Figure S5, photographs of the flowstone cores from WP, HC, NB and DC are shown. The samples analyzed in this study are marked in red.
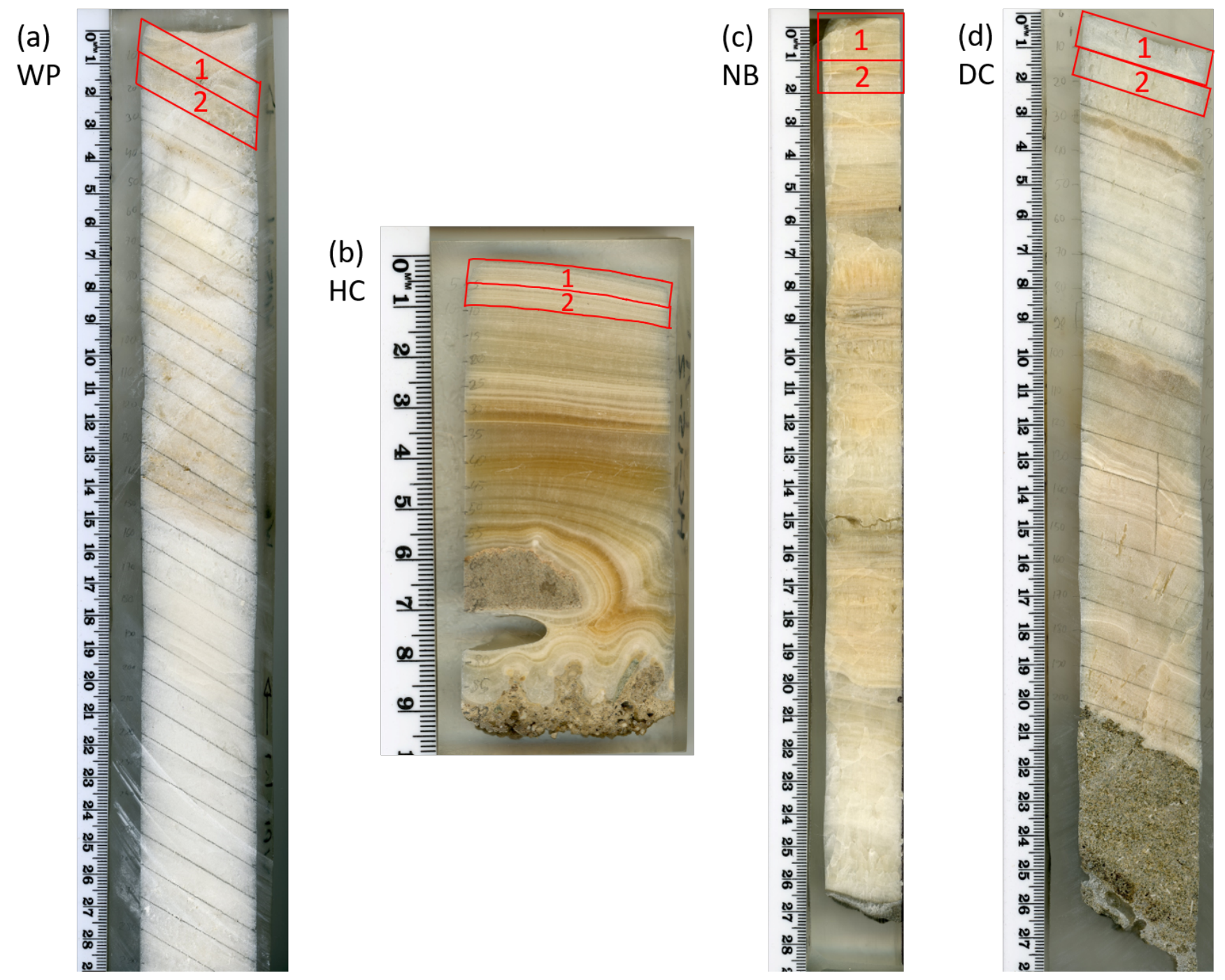

Figure S5. Photographs of the flowstone cores from (a) Waipuna Cave (WP), (b) Hodges Creek Cave (HC), (c) Nettlebed Cave (NB), and (d) Daves Cave (DC). The samples analyzed in this study are marked in red. 
Photographs of the flowstone slabs with the trenches drilled for ${ }^{230} \mathrm{Th} / \mathrm{U}$-dating are shown in Figure S6. All relevant data concerning the ${ }^{230} \mathrm{Th} / \mathrm{U}$-dating of the flowstone cores are shown in Table S1. Age-depth models of the four flowstone cores are shown in Figure S7.

(a)

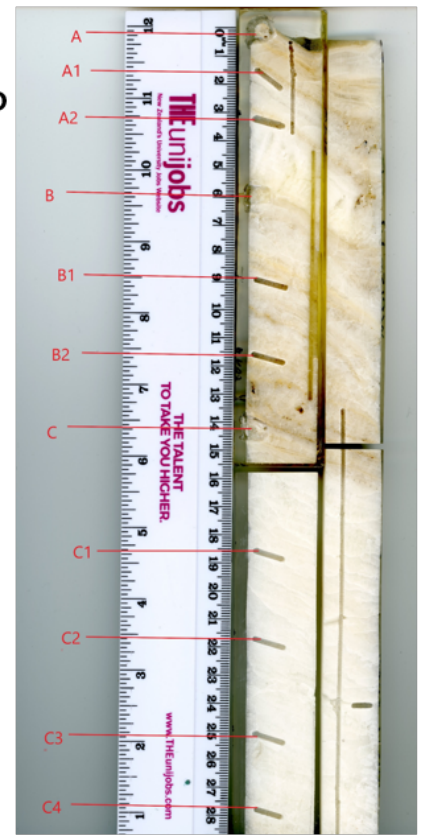

(b)

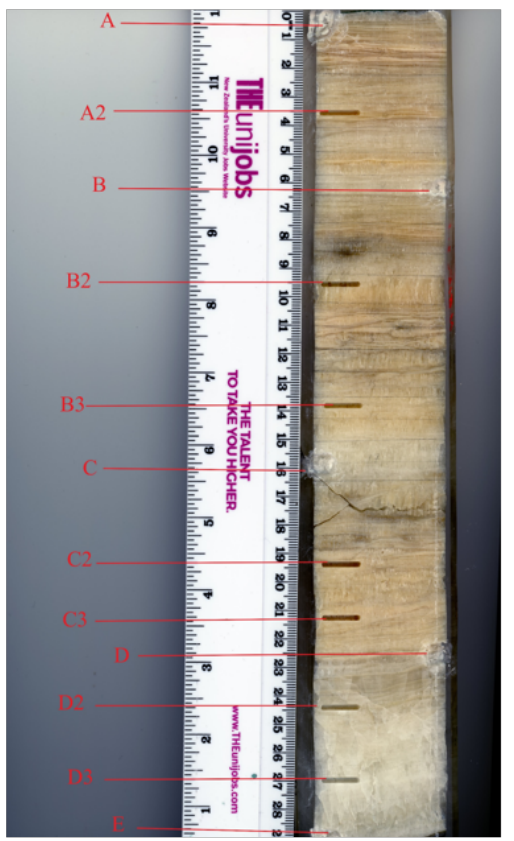

(c)

DC

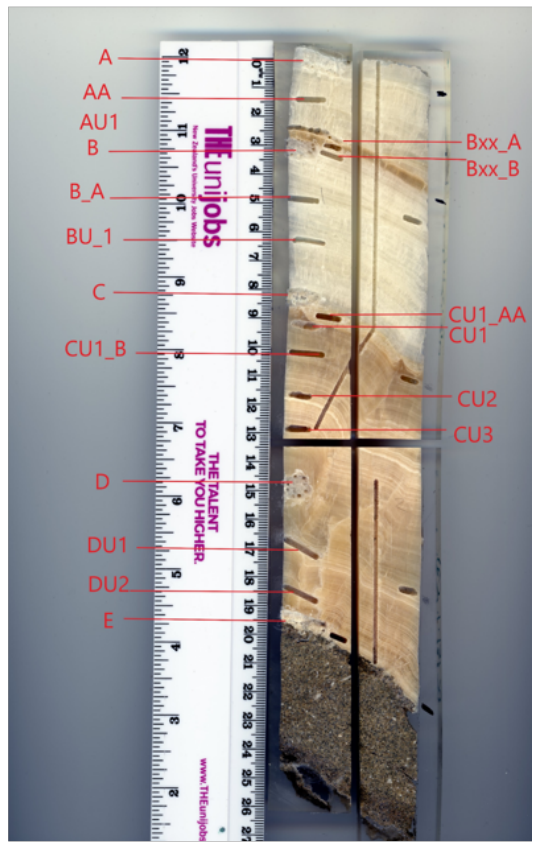

(d) DC

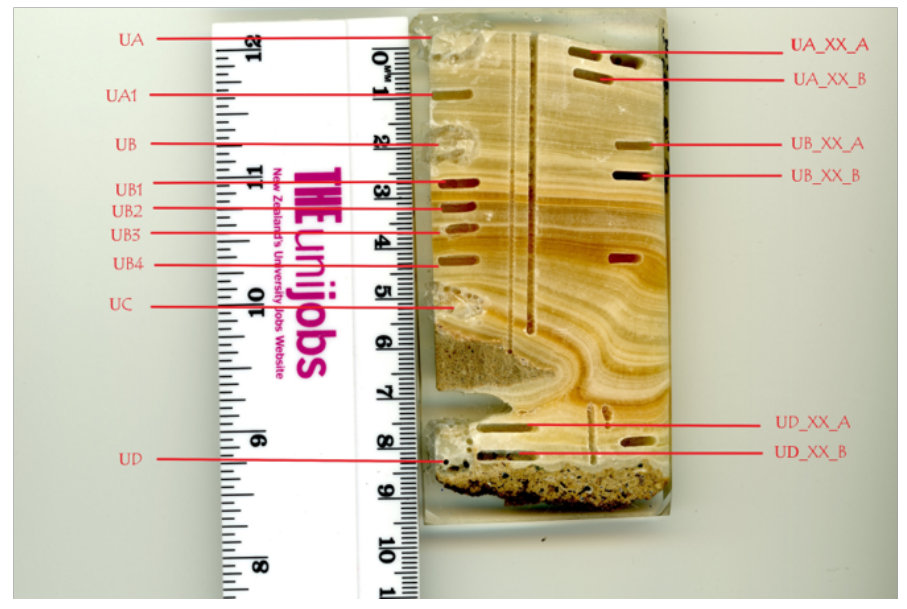

Figure S6. Photographs of the flowstone slabs with the trenches drilled for ${ }^{230} \mathrm{Th} / \mathrm{U}$-dating. 


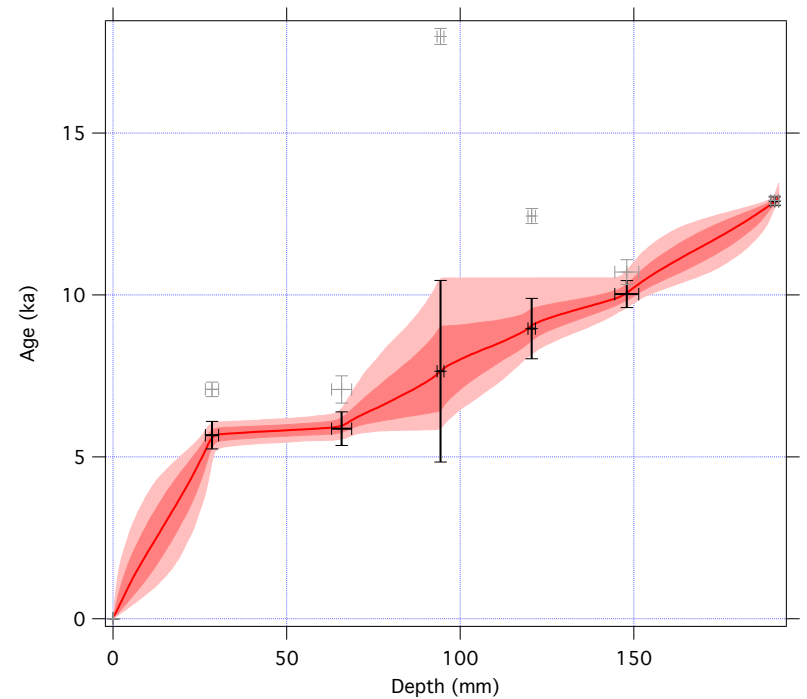

(a) Age-depth model of WP15-1.

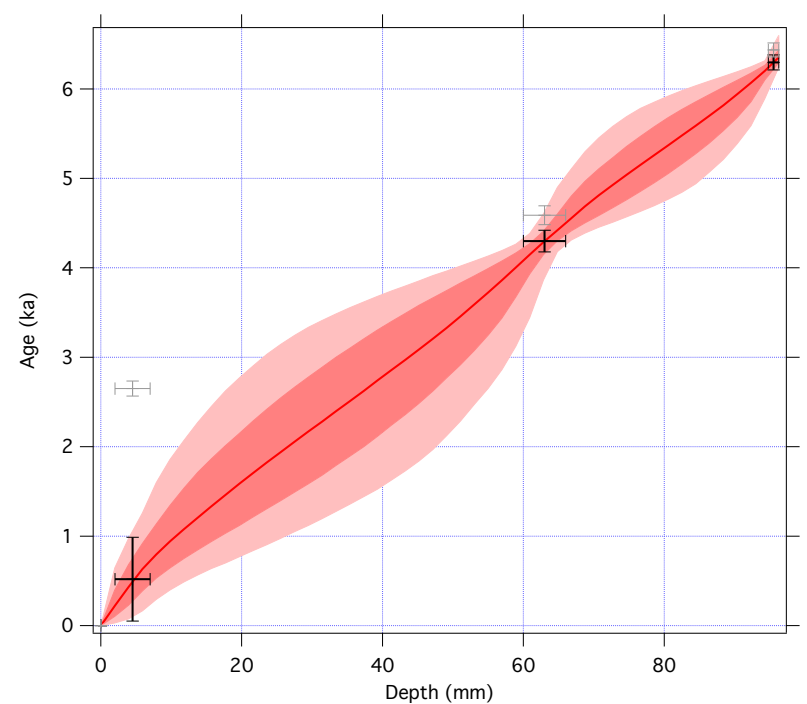

(c) Age-depth model of flowstone NB15.

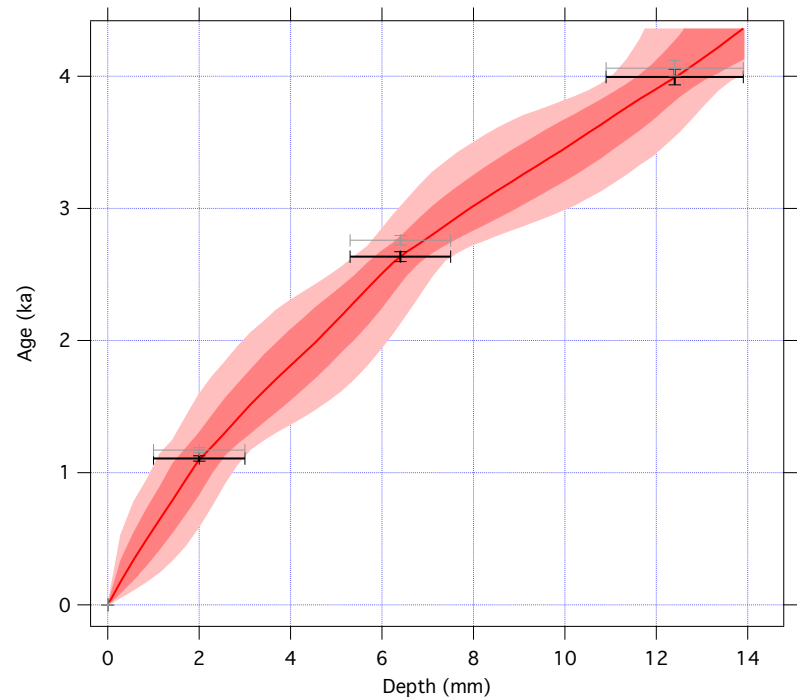

(b) Age-depth model of flowstone HC15.

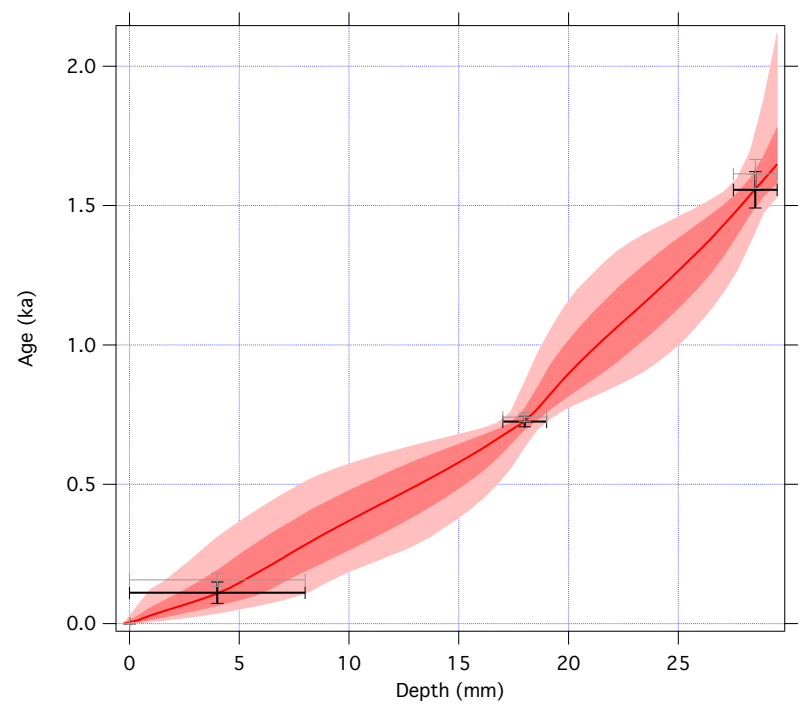

(d) Age-depth model of flowstone DC15.

Figure S7. Age-depth models of the four flowstone cores. 


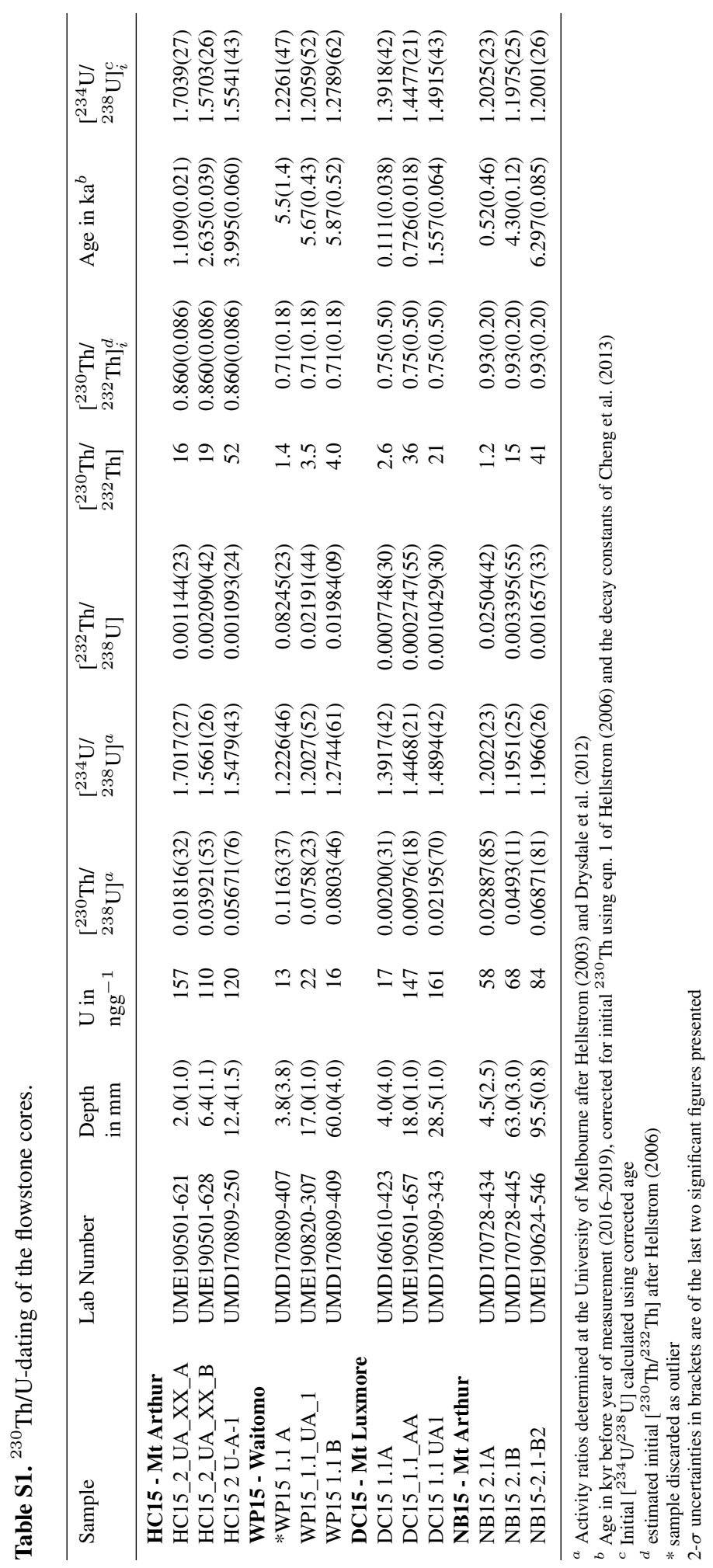




\section{S5 Data of LOP analysis}

In Tables S2, S3 and S4, the data of the LOP analysis are given. These data or simple calculations thereof were used to create Figures 3 to 7 in the manuscript.

Table S2. LOP data of flowstone samples.

\begin{tabular}{lrrrrrrrrr}
\hline Sample & C in ng/g & $\begin{array}{l}\text { C in } \% \\
\text { of } \Sigma 8\end{array}$ & \multicolumn{1}{c}{ S in ng/g } & $\begin{array}{l}\text { S in } \% \\
\text { of } \Sigma 8\end{array}$ & V in ng/g & $\begin{array}{l}\text { V in } \% \\
\text { of } \Sigma 8\end{array}$ & C/V & S/V & $\begin{array}{r}\Sigma 8 \text { in } \\
\text { ng/g }\end{array}$ \\
\hline WP1 & $17.6 \pm 0.8$ & 54.9 & $6.9 \pm 1.1$ & 21.5 & $7.6 \pm 0.9$ & 23.6 & $2.33 \pm 0.28$ & $0.91 \pm 0.18$ & 32.1 \\
WP2 & $23.5 \pm 1.6$ & 65.2 & $5.3 \pm 0.9$ & 14.6 & $7.3 \pm 0.8$ & 20.2 & $3.22 \pm 0.40$ & $0.72 \pm 0.15$ & 36.0 \\
NB1 & $26.7 \pm 1.4$ & 29.0 & $48.3 \pm 1.7$ & 52.6 & $16.8 \pm 0.8$ & 18.3 & $1.58 \pm 0.11$ & $2.87 \pm 0.17$ & 91.8 \\
NB2 & $12.3 \pm 0.8$ & 9.1 & $85.4 \pm 1.6$ & 62.8 & $38.3 \pm 1.1$ & 28.2 & $0.32 \pm 0.02$ & $2.23 \pm 0.07$ & 136.1 \\
HC1 & $9.6 \pm 0.9$ & 13.6 & $39.4 \pm 2.2$ & 55.6 & $21.8 \pm 1.6$ & 30.7 & $0.44 \pm 0.05$ & $1.81 \pm 0.17$ & 70.9 \\
HC2 & $35.3 \pm 1.8$ & 26.0 & $73.8 \pm 3.1$ & 54.4 & $26.7 \pm 1.9$ & 19.6 & $1.32 \pm 0.12$ & $2.77 \pm 0.23$ & 135.8 \\
DC1 & $23.3 \pm 0.6$ & 54.6 & $11.4 \pm 0.8$ & 26.7 & $8.0 \pm 0.7$ & 18.7 & $2.92 \pm 0.25$ & $1.43 \pm 0.15$ & 42.8 \\
DC2 & $14.0 \pm 0.5$ & 56.6 & $5.7 \pm 0.9$ & 22.9 & $5.1 \pm 0.7$ & 20.6 & $2.75 \pm 0.41$ & $1.11 \pm 0.24$ & 24.7 \\
\hline
\end{tabular}

Table S3. LOP data of XAD samples.

\begin{tabular}{lrrrrrrrrr}
\hline Sample & C in ng/g & $\begin{array}{c}\text { C in } \% \\
\text { of } \Sigma 8\end{array}$ & S in ng/g & $\begin{array}{l}\text { S in } \% \\
\text { of } \Sigma 8\end{array}$ & V in ng/g & $\begin{array}{l}\text { V in \% } \\
\text { of } \Sigma 8\end{array}$ & C/V & S/V & $\begin{array}{l}\Sigma 8 \text { in } \\
\text { ng/g }\end{array}$ \\
\hline XAD-CC4 & $35.4 \pm 7.7$ & 6.4 & $252.0 \pm 20.0$ & 45.3 & $268.9 \pm 61.5$ & 48.3 & $0.13 \pm 0.04$ & $0.94 \pm 0.23$ & 556 \\
XAD-DC1 & $62.6 \pm 6.7$ & 16.4 & $245.1 \pm 17.8$ & 64.0 & $75.1 \pm 42.6$ & 19.6 & $0.83 \pm 0.48$ & $3.27 \pm 1.87$ & 383 \\
XAD-DC2 & $33.7 \pm 4.7$ & 14.8 & $138.0 \pm 11.7$ & 60.5 & $56.2 \pm 34.6$ & 24.7 & $0.60 \pm 0.38$ & $2.46 \pm 1.52$ & 228 \\
XAD-HC3 & $76.4 \pm 5.0$ & 6.4 & $808.2 \pm 42.7$ & 67.2 & $318.6 \pm 29.9$ & 26.5 & $0.24 \pm 0.03$ & $2.54 \pm 0.27$ & 1203 \\
XAD-HC4 & $134.7 \pm 8.9$ & 3.5 & $2844.2 \pm 110.3$ & 73.7 & $877.8 \pm 92.8$ & 22.8 & $0.15 \pm 0.02$ & $3.24 \pm 0.36$ & 3857 \\
XAD-HC5 & $41.0 \pm 4.6$ & 6.0 & $507.3 \pm 24.5$ & 73.7 & $139.9 \pm 16.0$ & 20.3 & $0.29 \pm 0.05$ & $3.63 \pm 0.45$ & 688 \\
XAD-WP1b & $79.6 \pm 6.7$ & 11.3 & $466.5 \pm 15.2$ & 66.3 & $157.2 \pm 8.1$ & 22.3 & $0.51 \pm 0.05$ & $2.97 \pm 0.18$ & 703 \\
XAD-WP2 & $71.9 \pm 6.4$ & 5.0 & $673.9 \pm 32.2$ & 47.1 & $686.0 \pm 167.4$ & 47.9 & $0.10 \pm 0.03$ & $0.98 \pm 0.24$ & 1432 \\
XAD-WP3 & $55.8 \pm 5.6$ & 8.8 & $368.5 \pm 21.9$ & 58.4 & $206.8 \pm 24.0$ & 32.8 & $0.27 \pm 0.04$ & $1.78 \pm 0.23$ & 631 \\
\hline
\end{tabular}




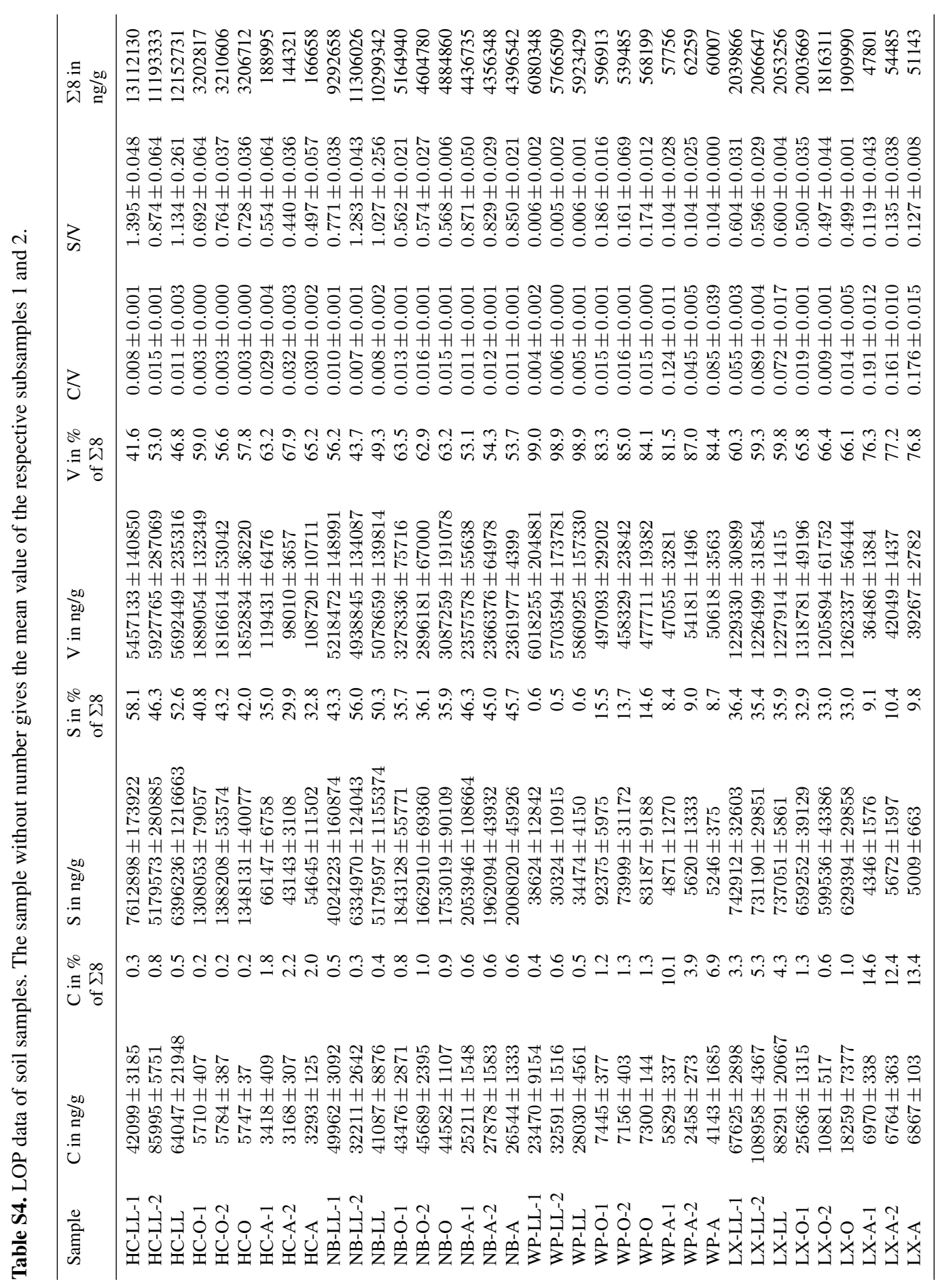




\section{References}

Cheng, H., Lawrence Edwards, R., Shen, C.-C., Polyak, V. J., Asmerom, Y., Woodhead, J., Hellstrom, J., Wang, Y., Kong, X., Spötl, C., Wang, X., and Calvin Alexander, E.: Improvements in ${ }^{230} \mathrm{Th}$ dating, ${ }^{230} \mathrm{Th}$ and ${ }^{234} \mathrm{U}$ half-life values, and U-Th isotopic measurements by multi-collector inductively coupled plasma mass spectrometry, Earth and Planetary Science Letters, 371-372, 82-91, https://doi.org/10.1016/j.epsl.2013.04.006, 2013.

Drysdale, R. N., Paul, B. T., Hellstrom, J. C., Couchoud, I., Greig, A., Bajo, P., Zanchetta, G., Isola, I., Spötl, C., Baneschi, I., Regattieri, E., and Woodhead, J. D.: Precise microsampling of poorly laminated speleothems for U-series dating, Quaternary Geochronology, 14, 38-47, https://doi.org/10.1016/j.quageo.2012.06.009, 2012.

Heidke, I., Scholz, D., and Hoffmann, T.: Quantification of lignin oxidation products as vegetation biomarkers in speleothems and cave drip water, Biogeosciences, 15, 5831-5845, https://doi.org/10.5194/bg-15-5831-2018, 2018.

Hellstrom, J.: Rapid and accurate U/Th dating using parallel ion-counting multi-collector ICP-MS, Journal of Analytical Atomic Spectrometry, 18, 1346, https://doi.org/10.1039/b308781f, 2003.

Hellstrom, J.: U-Th dating of speleothems with high initial ${ }^{230}$ Th using stratigraphical constraint, Quaternary Geochronology, 1, 289-295, https://doi.org/10.1016/j.quageo.2007.01.004, 2006.

15 Hewitt, A. E.: New Zealand soil classification, vol. no. 1 of Landcare Research science series, 1172-269X, Manaaki Whenua Press, Lincoln N.Z., 3rd ed. edn., 2010.

Nava-Fernandez, C., Hartland, A., Gázquez, F., Kwiecien, O., Marwan, N., Fox, B., Hellstrom, J., Pearson, A., Ward, B., French, A., Hodell, D. A., Immenhauser, A., and Breitenbach, S. F. M.: Pacific climate reflected in Waipuna Cave drip water hydrochemistry, Hydrology and Earth System Sciences, 24, 3361-3380, https://doi.org/10.5194/hess-24-3361-2020, 2020. 